\title{
Reseña del libro Barros, Carlos, La base material de la nación. El concepto de nación en Marx y Engels, Barcelona, El Viejo Topo, 2020, 220 páginas
}

\author{
Carlos Astarita \\ carlos.astarita@gmail.com \\ Universidad Nacional de La Plata, Argentina
}

Recepción: 31 Octubre 2020

Aprobación: 03 Noviembre 2020

Publicación: 10 Diciembre 2020

Cita sugerida: Astarita, C. (2020). [Revisión de libro La base material de la nación. El concepto de nación en Marx y Engels, de C. Barros]. Sociedades Precapitalistas, 10, e053. https://doi.org/10.24215/22505121e053

Carlos Barros es bien conocido por los medievalistas argentinos, por sus estudios sobre la opresión señorial en Galicia (p.e. el derecho de pernada) y las luchas campesinas contra esa intolerable servidumbre (Barros, 1998). También es conocido, más allá del medievalismo, por crear e impulsar Historia a Debate, un movimiento iniciado en congresos internacionales celebrados en Santiago de Compostela (en 1993 y 1999), que hoy, gracias a Internet, es el canal de comunicación más importante de historiadores sociales hispano parlantes. Esto habla de sus intereses metodológicos e historiográficos, a los que ha dedicado una buena parte de sus publicaciones, y en este campo se inscribe el libro que ahora se reseña.

Su objetivo se enuncia en el título: el concepto de nación en Marx y Engels. Lo contrapone al que Stalin elaboró en 1913 (predominante en el movimiento comunista), y que definía a la nación como una comunidad estable, surgida de una comunidad de idioma, territorio, condiciones económicas y psicología. Contra esta concepción subjetivista (la economía era solo una parte más de los atributos), el autor mostrará la de Marx y Engels, que ponían en el centro las condiciones de producción. Estas no solo abarcan las relaciones de producción sino también elementos naturales, históricos y sociales, lo que implica tomar en cuenta la lucha de clases. Esto entraña por un lado el problema de desarrollar una teoría unificada de nación y clase, y por otro implica historizar el problema, porque esas condiciones de producción no son atemporales ni tampoco fijas. 
Nos introducimos así en otra dimensión, que también se vincula estrechamente con el autor, porque Barros ha sido un activo militante sindical y político del Partido Comunista en época del franquismo (lo que le valió detención y tortura), compromiso ideológico que nunca abandonó. Política e historiografía se unen entonces en este libro de la manera más natural, y en ese marco se explica que el autor enfatice que las condiciones que crean la nación moderna son también las de su superación con la revolución del proletariado, en tanto las contradicciones entre naciones tienen su origen, en última instancia, en las contradicciones de clase. Con la nación proletaria habrá relaciones nacionales que son negadoras de la explotación, y vinculado con esto, al autor no le es indiferente la práctica política de Marx y Engels. La guiaron dos criterios básicos: (1) una nación que oprime a otra no puede ser libre y (2) los comunistas hacen valer los intereses comunes de todo el proletariado. Esto se diferenció del criterio que prevaleció desde fines del siglo XIX, cuando se puso en primer término la autodeterminación nacional y las colonias.

El análisis de Marx y Engels lo emprende Barros sumergiéndose directamente en las fuentes (no solo en los libros sino también en la correspondencia y en los artículos periodísticos), destacando una unidad de pensamiento que no segrega a Engels, como a veces se hizo inscribiéndolo erradamente en un materialismo mecanicista.

Barros pasa revista a los términos intercambiables en Marx y Engels de nación, pueblo, país, patria, y a sus análisis concretos: Irlanda, Provenza, papel de la burguesía en la formación nacional, modelos clásicos y anómalos de ese proceso, diferenciada intervención de formas coactivas en las economías, y Alemania, donde la nación fue un producto del conjunto de las clases y no solo de la burguesía ascendente, historia que desde la derrota campesina en 1525 permite comprender, incluso, la política de la socialdemocracia. Como no podía ser de otro modo, revisa las ideas de Marx sobre la India y China, que incluían la tesis de que los países atrasados seguirían a los de capitalismo desarrollado, predicción que en el largo plazo se cumple con la incorporación del Tercer Mundo al sistema capitalista. Esas consideraciones acompañaron la denuncia de las atrocidades del colonialismo. También alude a los papeles políticos que Marx y Engels veían jugar en los países: Rusia era el centro de la contrarrevolución y Polonia era una cuña revolucionaria en Europa.

Si una cuestión queda en claro en este libro es la importancia que tuvieron para Marx y Engels las condiciones materiales en la configuración de las naciones (aunque no descartaban la subjetividad), lo cual presupone un análisis complejo por las ricas determinaciones que tiene una formación social, praxis intelectiva que no tiene nada que ver con la filosofía de la historia. Tampoco se asimila al esquema estructuralista, armado por la sencilla articulación entre modos de producción, en tanto Marx y Engels integraban condiciones naturales e históricas en una dialéctica de interacciones. En esa dinámica vieron subyacer un elemento de continuidad y renovación, dado por las fuerzas productivas, lo cual replantea la continuidad/discontinuidad entre períodos históricos, conexión que en gran parte constituye la historia nacional. También analiza cómo se consideró la relación entre génesis y estructura, especialmente importante en las invasiones de pueblos, problema tratado por Perry Anderson en relación a los orígenes de la Edad Media. Asimismo las condiciones de producción se ligan a las de reproducción, que en el capitalismo se dan en contextos nacionales

Pero la nación es también un mediador que encubre la desigualdad de clases bajo la apariencia de una igualdad mistificadora que se apoya en la comunidad real, y en este punto Barros toca un aspecto cardinal de la ideología como elemento de lo real. En suma, la nación es una mediación social que es fuente de falsa conciencia y le permite al capital su control. Con todo esto en danza, se plantea la relación entre luchas nacionales e internacionales, internas de clases o entre naciones.

Con el centro de la atención puesta en los fundadores del marxismo, el autor no deja de hacer observaciones críticas sobre Dov Ber Borojov, Pierre Vilar, Otto Bauer y Emmanuel Teray. Pero lo fundamental es una investigación poco habitual en su tipo, aunque no faltan algunos ejemplos de un similar rastreo de otros temas sobre las mismas fuentes (Godelier (1971); Pryor (1996); Kalmring y Nowak (2011)). Esas contribuciones, al igual que el libro que ahora se reseñó, nos recuerdan que en Marx y Engels el historiador encuentra 
inspiraciones y orientaciones para pensar sus trabajos. La investigación de Barros y sus reflexiones son una valiosa contribución en ese sentido.

\section{ReFERENCIAS}

Barros, C. (1998). Mentalidad justiciera de los irmandiños, siglo XV. Madrid: Siglo XXI.

Godelier, M. (1971). Teoría marxista de sociedades precapitalistas. Barcelona: Estela.

Kalmring, S. y Nowak, A. (2011). «Marx über den Kolonialismus. Kolonialismus und antikolonialer Widerstand als Lernprozess und Erkenntnisbewegung». Z. Zeitschrift Marxistische Erneuerung, 85. www.zeitschriftmarxistische-erneuerung.de

Pryor, J. (1996) «Karl Marx and the Medieval Economy», Arts. The Journal of the Sydney University Arts Association, XVIII, pp. 68-86 